\title{
A Study on Hydrogeochemistry of Ground Water Near Mining Activity Area by Using Multivariate Factor Analysis
}

\author{
Ch. V. V. Satyavani ${ }^{1}$, P.V.S. Machiraju ${ }^{2}$, B. Venkateswara Rao ${ }^{3}$ \\ ${ }^{1}$ V.S.Lakshmi Women's Degree \& P.G. College, Kakinada, A.P \\ ${ }^{2}$ Department of Engineering Chemistry, Pragati Engineering College, Surampalem, A.P \\ ${ }^{3}$ Dept.of Engineering Chemistry, A.U. College of Engineering, Visakhapatnam, A.P \\ kvvsatyavani@yahoo.com
}

\begin{abstract}
The objective of the present research study is to evaluate the quality of ground water near mining activity area in East Godavari District of Andhra Pradesh. Ground water samples were collected from the nearby granite mining activity area and characterized for physico chemical parameters viz., $p H$, Electrical Conductivity(EC), Total dissolved Solids(TDS), Total Hardness(TH), Total Alkalinity(TA), Calcium $\left(\mathrm{Ca}^{2+}\right)$, Magnesium $\left(\mathrm{Mg}^{2+}\right)$,Sodium $\left(\mathrm{Na}^{+}\right)$, Potassium $\left(\mathrm{K}^{+}\right)$, Chloride $(\mathrm{Cl})$, Sulphate $\left(\mathrm{So}_{4}{ }^{2-}\right)$, Phosphate $\left(\mathrm{Po}_{4}{ }^{3-}\right)$, Nitrate $\left(\mathrm{NO}_{3}{ }^{-}\right)$. The research results revealed that these waters were unsuitable for drinking or domestic application due to higher chemical parametric levels compared to the drinking water standards of IS: 10500-1992. Factor analysis was performed for the parametric data set. This provides an insight into the source of parameters which are responsible for the water quality changes that occur in the ground water. The present study elucidated the effectiveness of factor analysis in evaluating the changes in ground water quality which is dominated by natural and anthropogenic activities.
\end{abstract}

Key words: Ground water, mining, quality, drinking, health.

\section{INTRODUCTION}

Water is essential to all forms of life. Usage of water and exploitation of land and water resources and also pollution contribute to the degradation in the quality of environment [1]. Mining activities, Industrialization, Urbanization and Agricultural activities become fragile and will become a cause for concern [2]. Surface Mining attributes pollution to ground water by flow of contaminated drainage from the mine. Human activities which include mining, threaten the water sources [3]. The importance of water in our day to day life makes us to carry out physicochemical and microbiological examinations for water periodically to check the water quality for confirming that it is free from disease causing microorganisms and chemical constituents which are hazardous to health [4]. Multivariate analysis is highly useful due to its relative significance in evaluating the combination of large chemical variable data set as they will become helpful analytical tools to reduce and organize large hydrogeochemical data sets into particular groups with similar characteristics. The rotated factor analysis is widely employed as a statistical technique in hydro-geo chemistry. The analysis is highly useful for the interpretation of the ground water quality data and relating them to specific changes in hydro- geological processes. The factor analysis has been successfully applied to sort out of hydro-geochemical processes from the collected ground water quality data [5-9]. The main purpose of such analysis for the study of the hydro geochemistry of an aquifer is to find a set of factors, few in number, which can explain a large amount of the variance of the analytical data. 


\section{Ch. V. V. Satyavani et al.}

The objective of this research study is to characterize the Ground Water samples collected in the nearby areas of the granite mining area located in Yellamilli of East Godavari District, Andhra Pradesh for physicochemical parameters for assessment of quality for the Better end application

\section{MATerials AND Methods}

The study area is located in East Godavari District of Andhra Pradesh between the Co-ordinates $17^{0} .11^{1} \mathrm{~N}$ and $82^{0} .26^{1} \mathrm{E}$ and the study area map is represented in Diagram-1.
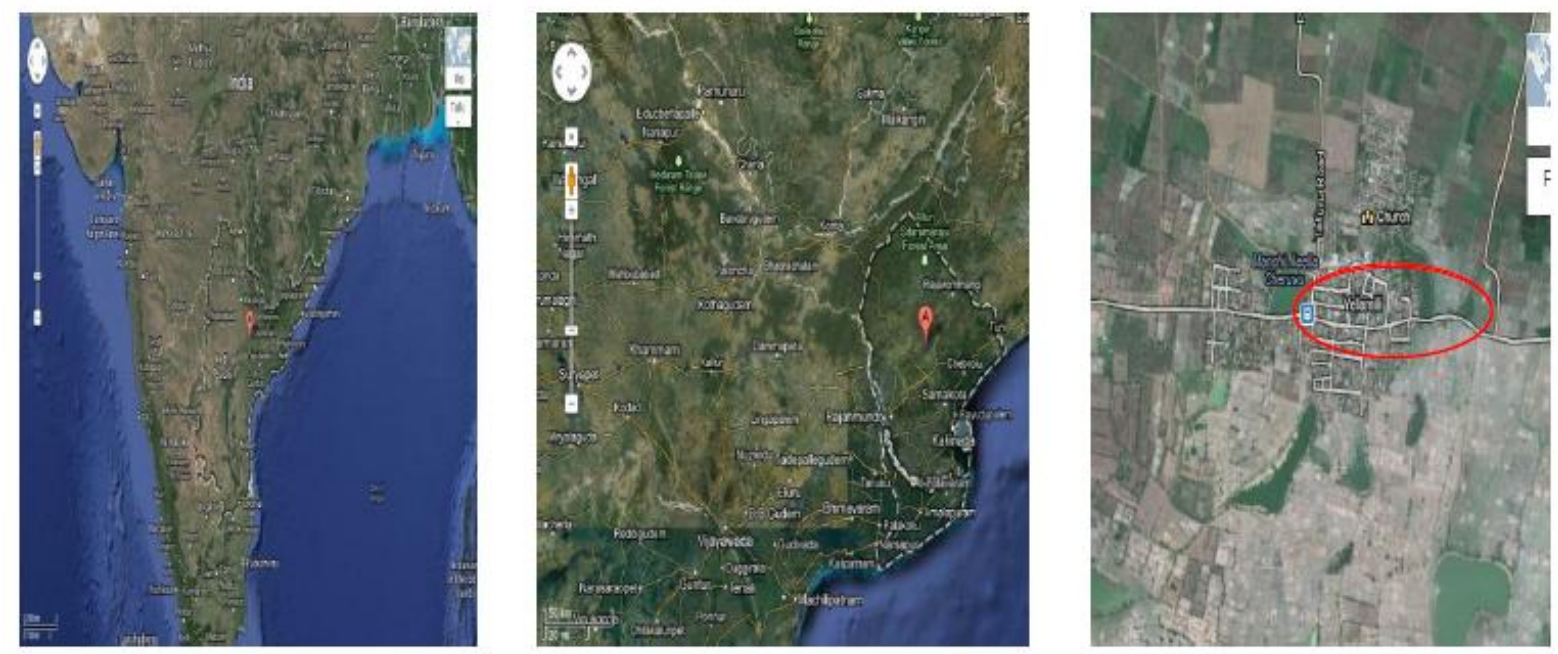

Diagram1. Study Area Map

Ground water samples were collected around a radius of $2 \mathrm{~km}$ from Mining activity area towards East, and West, North and South directions. The details of sampling code and locations are presented in Table-1

Table1. Details of Sample code and Sampling location

\begin{tabular}{|c|c|}
\hline Sampling location & Direction/Distance \\
\hline Near Mine & East $(0 \mathrm{~km})$ \\
\hline Sugar cane Field & East $(1 \mathrm{~km})$ \\
\hline Sugar cane Field & East $2 \mathrm{~km})$ \\
\hline Near Cotton Field & North $(0 \mathrm{~km})$ \\
\hline Sugar cane Field & North $(\mathrm{I} \mathrm{km})$ \\
\hline Sugar Cane Field & North $(2 \mathrm{~km})$ \\
\hline Near Cotton Field & West $(0 \mathrm{~km})$ \\
\hline Banana Garden & West $(\mathrm{I} \mathrm{km})$ \\
\hline Cotton crop & West $(2 \mathrm{~km})$ \\
\hline Cotton Field & South $(0 \mathrm{~km})$ \\
\hline Cattle shed Near Road & South $(1 \mathrm{~km})$ \\
\hline Towards Talluru village Road & South $(2 \mathrm{~km})$ \\
\hline
\end{tabular}

Containers made of polythene were employed for sampling of ground water and preserved for analysis as per the standard procedures [10]. Twelve ground water samples were collected and analyzed for physicochemical parameters viz., $\mathrm{pH}, \mathrm{EC}, \mathrm{TDS}, \mathrm{TA}, \mathrm{TH}, \mathrm{Ca}^{2+}, \mathrm{Mg}^{2+}, \mathrm{Na}^{+}, \mathrm{K}^{+}, \mathrm{Cl}^{-}, \mathrm{SO}_{4}{ }^{2-}$, $\mathrm{NO}_{3}{ }^{-}$and $\mathrm{PO}_{4}{ }^{3-}$. $\mathrm{pH}$ was determined by $\mathrm{pH}$ meter (Global-DPH 505, India - Model) and conductivity measured by the digital conductivity meter (Global-DCM-900-Model), TDS calibrated from the relation TDS= Electrical conductivity $(\mathrm{EC}) \mathrm{x} 0.64$. Total Hardness, Total Alkalinity and Chloride were estimated by Titrimetry. Sulphate and Phosphate measured by Spectrophotometer (Vissican167, Systronics), Na and K by Flame photometry (Systronics). 
The ground water samples were analyzed as per the standard procedures [11] for physicochemical characteristics and the analytical data is presented in Table 2.

\subsection{Processing of Data}

The analytical data was used as variable inputs for factor analysis and performed by employing SPSS package described by Nie, the data was standardized according to criteria [12]. This procedure renders a new rotated factor varimax (Table-2) in which each factor was described in terms of only those variables and affords greater ease for interpretation. Factor loading is an indicator of the degree of closeness between the variables and the factor analysis provides several positive features that allow interpretation of the data set.

By verifying the factor loadings, communalities and Eigen values the variable belonging to a specific chemical process can be identified and the significance of the major parameters can be evaluated in terms of the total data set and in terms of each factor. Communality is an indicator of the error term. The factor scores for each sample and reflect the importance of a given factor at that sample site, the factor scores can be counted for each factor and for evaluating the aerial importance of the chemical process represented by that factor. Factor scores can be related to intensity of the chemical process described by each factor [13]. Extreme negative numbers $(<-1)$ reflect areas essentially unaffected by the process and positive scores $(>+1)$ reflect areas most affected. Near zero scores approximate areas affected to an average degree by the chemical process of that particular factor.

Table2. Physico-chemical characteristics of Ground Water

\begin{tabular}{|c|c|c|c|c|c|}
\hline \multicolumn{7}{|c|}{ Rotated Factor Pattern of Water Analysis data } & Final \\
\hline Parameter & Factor-1 & Factor-2 & Factor-3 & Factor-4 & Communalities \\
\hline $\mathrm{pH}$ & 0.14692 & -0.82962 & 0.3395 & 0.05149 & 0.82776181 \\
\hline $\mathrm{EC}$ & 0.80171 & 0.48301 & 0.07728 & 0.22313 & 0.93179717 \\
\hline $\mathrm{TDS}$ & 0.80097 & 0.4842 & 0.07729 & 0.22363 & 0.93199063 \\
\hline $\mathrm{TH}$ & 0.08643 & 0.01089 & 0.96912 & -0.09675 & 0.95614414 \\
\hline $\mathrm{TA}$ & 0.8933 & 0.01419 & 0.11264 & 0.03368 & 0.81201077 \\
\hline $\mathrm{Na}^{+}$ & 0.88177 & -0.01685 & 0.03384 & 0.09442 & 0.78786354 \\
\hline $\mathrm{K}^{+}$ & 0.78085 & -0.2411 & -0.33288 & -0.39319 & 0.93326337 \\
\hline $\mathrm{Ca}^{2+}$ & 0.05423 & 0.907 & 0.00692 & -0.20913 & 0.86937687 \\
\hline $\mathrm{Mg}^{2+}$ & 0.03611 & -0.18764 & 0.97366 & 0.03963 & 0.98609287 \\
\hline $\mathrm{Cl}^{-}$ & 0.82106 & 0.40068 & 0.17232 & 0.18898 & 0.90009811 \\
\hline $\mathrm{SO}_{4}{ }^{2-}$ & 0.48291 & 0.72194 & -0.20546 & 0.04171 & 0.79836253 \\
\hline $\mathrm{NO}_{3}{ }^{-}$ & 0.21621 & -0.25379 & -0.08462 & 0.91016 & 0.94670649 \\
\hline $\mathrm{PO}_{4}{ }^{3-}$ & 0.47534 & 0.78294 & 0.23767 & -0.11202 & 0.90798029 \\
\hline Eigen Value & 5.71347599 & 2.73259563 & 2.07321426 & 1.07016272 & \\
\hline Total Variance & 4.6828866 & 3.431751 & 2.274659 & 1.200152 & 11.58944859 \\
\hline$\% \mathrm{Variance}^{-}$ & 40.40646596 & 29.6109946 & 19.6269821 & 10.35555739 & \\
\hline $\mathrm{Cummulative} \%^{-40.40646596}$ & 70.0174606 & 89.6444427 & 100.0000001 & \\
\hline
\end{tabular}

\section{RESULTS AND DISCUSSION}

The four factors show eigen values $>1$ hence they were considered.

Factor1: Loaded heavily with EC, TDS, TA, $\mathrm{Na}^{+}, \mathrm{K}^{+}, \mathrm{Cl}^{-}$(Table-2) indicating that factor-1 can be associated with saline nature. This factor accounts for $40.40 \%$ of variance, concentration of the 
ground water samples and is higher percentage than attributed to the other factors. Ground waters are highly affected due to the presence of soluble solids and saline nature and hence its quality was depleted.

Factor2: Loaded largely with $\mathrm{Ca}^{2+}, \mathrm{SO}_{4}{ }^{2-}$ and $\mathrm{PO}_{4}{ }^{3-}$. This factor accounts for $29.61 \%$ of variance. The higher concentration of Calcium and Phosphate indicate the excessive interaction of water with aquifer formations due to the usage of fertilizers for crops in the surrounding areas also. Higher concentration of sulphate indicate the discharge of some industrial effluents from the surrounding areas into the ground waters.

Factor3: Accounts for $19.62 \%$ of variance and mainly represented by $\mathrm{TH}$ and $\mathrm{Mg}^{2+}$. The higher concentrations of $\mathrm{Mg}^{2+}$ may be due to sediment water interaction and weathering process of the rocks in these surrounding areas. TH indicate the encrustation nature of waters.

Factor4: Indicates mainly Nitrate $\mathrm{NO}_{3}{ }^{-}$and this factor accounts for $10.35 \%$ of variance. The higher concentration of Nitrate may be due to the discharge of agricultural runoff from the nearby surrounding areas.

\section{Conclusion}

The result of multivariate statistical analysis as applied to the chemical analytiacal data set of ground water in the present study area provides an insight into the underlying factors controlling hydro geo chemical processes in the region. Four factors indicating Factor-1(EC, TDS, TA, $\mathrm{Na}^{+}, \mathrm{K}^{+}$and $\mathrm{Cl}^{-}$) ; Factor- $2\left(\mathrm{Ca}^{2+}, \mathrm{SO}_{4}{ }^{2-}, \mathrm{PO}_{4}{ }^{3-}\right)$; Factor- $3\left(\mathrm{TH}, \mathrm{Mg}^{2+}\right)$ and Factor-4 $\left(\mathrm{NO}_{3}{ }^{-}\right)$expected from the data set represent the signatures of contamination with chemical parameters. Factor-1 represents the parameters with dominant concentrations and contributors to the ground water saline nature. Factor-2 resulted from the data set also indicate the signatures of anthropogenic activities in the study area. Factor-3 and Factor-4 clearly indicate the impacts of human made activities in the study area. The present study demonstrated usefulness of factor analysis in interpreting the hydro geo chemistry data and relating to the ground water salinity and other chemical contamination due to anthropogenic activities. The technique can be extended to any aquifer as a compliment to standard hydro geo chemical method. Further, the numerical analysis can help to resolve ambiguities and provide unique hydro geo chemical information.

\section{ACKNOWLEDGEMENT}

The authors extend their sincere thanks to Miss.K.Surekha Faculty, Department of Statistics, P.R.Govt.College(A), Kakinada for her cooperation in presenting the statistical data in the present research work.

\section{REFERENCES}

[1] Udiba U.U.,Akpan E.R.,Ogabiela E.E.,Magomya A.M., Yebpella G.G., Apngo-Nwosu T.U. , Hammuel C., Ade-Ajayi A.F. and Aina.O.B., Journal of Basic and Applied Scientific Research,2(2),2012, 1658-1666.

[2] Shivaraju H.P. , Int.J.Res.Chem.Environ., Vol.2 (1),(2012),44-53.

[3] Safe drinking water foundation, www.safewater.org

[4] Shittu O.B., Olaitan J.O., and Amusa T.S., African Journal of Biomedical Research, Vol.11, (2008), 285-290.

[5] Hitchon B., Billings G.K and Kolvan J.E., Geochemistry and origin of formation waters in the Western Canada sedimentary basin.111. Factors controlling chemical composition. Geochim Acta 35:(1971), 567-598. 
[6] Lawrence F.W., Upchurch S.B., Identification of recharge areas using geochemical factor analysis. Ground water 20(1971), 680-687.

[7] Seyhan E.R., Van De Caried A.A. and Engelen G.B., Multivariate analysis and interpretation of the hydrogeochemistry of dolomite reef aquifer, Northern Italy. Water Resou Res 21(1985), 1010-1024.

[8] Razack M Dazy J., Hydro chemical characterization of ground water mixing in sedimentary and metamorphic reservoirs with combined use of piper's principal and factor analysis. J Hydrol 114(1990), 371-393.

[9] Jeyakumar R. and Siraz.L., Factor analysis in hydro geochemistry of coastal aquifers - A preliminary study, Environmental Geology 31( 1996), 174-177.

[10] Ramteke D.S. and Moghe C.A., Mannual on water \& waste water analysis, National Environmental Engineering Research institute, Nagpur, India (1998).

[11] APHA standard method for the examination of water and waste water, American public Health Association, Washington, $19^{\text {th }}$ ed. (1992).

[12] Davis J.C., Statistics and data analysis in geology. Wiley, New York(1973),pp 550.

[13] Dalton M.G. and Upchurch S.B., Interpretation of hydro chemical facies by factor analysis. Groundwater 16, 1978, 228-233. 